\title{
RESPON KACANG HIJAU (Vigna radiata L.) VARIETAS MURAI TERHADAP KOMBINASI PEMBERIAN BEBERAPA JENIS PUPUK PADA TANAH ULTISOL
}

\author{
Rendi Hermawan, Effi Yudiawati \\ Program Studi Agroteknologi Fakultas Pertanian Universitas Muara bungo \\ Artikel Diterima 18 November 2020, disetujui 10 Januari 2021
}

ABSTRAK

Penelitian ini dilaksanakan dilahan percobaan Fakultas Pertanian Universitas Muara Bungo, dengan ketinggian 101 meter diatas permukaan laut, dengan temperatur udara berkisar antara $25^{\circ} \mathrm{C}-31^{\circ} \mathrm{C}$, dengan rata-rata curah hujan per bulan adalah $179-279 \mathrm{~mm}$ pada bulan basah dan $68-106 \mathrm{~mm}$ pada bulan kering dengan tanah jenis Ultisol. Penelitian ini dilaksanakan pada tanggal 01 Desember sampai dengan 28 Februari 2017. Penelitian ini bertujuan untuk mengetahui respon Kacang Hijau Varietas Murai terhadap pemberian kombinasi beberapa jenis pupuk pada tanah Ultisol dan untuk mengetahui kombinasi pemberian beberapa jenis pupuk yang terbaik terhadap tanaman kacang hijau varietas murai pada tanah Ultisol.

Penelitian ini menggunakan Rancangan Acak Kelompok (RAK) dengan 5 perlakuan dan 4 kelompok. Adapun perlakuan sebagai berikut : P0 (Pupuk Dolomit 0 t/ha,Pupuk KCL $0 \mathrm{~kg} / \mathrm{ha}$ dan Fermentasi Urine Sapi $0 \mathrm{ml} / \mathrm{l}$ air), P1 (Pupuk Dolomit $2 \mathrm{t} / \mathrm{ha}$, Pupuk KCL 25 $\mathrm{kg} / \mathrm{ha}$ dan Fermentasi Urine Sapi $100 \mathrm{ml} / \mathrm{l}$ air), P2 (Pupuk Dolomit 4 t/ha, Pupuk KCL 50 kg/ha dan Fermentasi Urine Sapi $200 \mathrm{ml} / \mathrm{l}$ air), P3 (Pupuk Dolomit 6 t/ha, Pupuk KCl 75 kg/ha dan Fermentasi Urine Sapi 300 ml/l air) dan P4 (Pupuk Dolomit 8 t/ha, Pupuk KCl 100 $\mathrm{kg} / \mathrm{ha}$ dan Pupuk Urine Sapi $400 \mathrm{ml} / \mathrm{l}$ air). Adapun parameter yang diamati adalah tinggi tanaman $(\mathrm{cm})$, jumlah cabang primer $(\mathrm{cm})$, diameter batang pokok $(\mathrm{cm})$, jumlah polong isi pertanaman (buah), jumlah biji pertanaman (biji) dan hasil biji kering per hektar (ton). Hasil pengamatan dianalisis secara statistik dengan analisis ragam dan apabila terdapat pengaruh nyata maka dilanjutkan dengan uji duncan's multiple range test (DNMRT) taraf 5\%.

Hasil penelitian menunjukan bahwa respon kacang hijau varietas murai terhadap variabel tinggi tanaman $(\mathrm{cm})$ dan lingkar batang $(\mathrm{cm})$ menunjukan respon yang sama sementara pada jumlah cabang primer (buah), jumlah polong isi per tanaman (buah), jumlah biji pertanaman (biji) dan hasil biji kering per hektar (ton) memberikan respon yang berbeda. Respon kacang hijau varietas murai pada perlakuan P1 (dolomit 2 t/ha + KCL 25 $\mathrm{kg} / \mathrm{ha}+100 \mathrm{ml} / \mathrm{l}$ air Fermentasi Urine sapi) merupakan perlakuan terbaik di tanah Ultisol.

\section{Kata Kunci : Kombinasi beberepa Jenis Pupuk, kacang hijau varietas murai pertumbuhan dan hasil}

\section{PENDAHULUAN}

Kacang hijau (Vigna Radiata L.) merupakan tanaman legum yang cukup penting di Indonesia dan posisinya menduduki tempat ketiga setelah kedelai dan kacang tanah. Rukmana (2006) menyatakan bila dibandingkan dengan kacang-kacangan lain, kacang hijau memiliki kelebihan antara lain berumur genjah, lebih toleran kekeringan, dapat ditanam dilahan kurang subur dan sekaligus bisa sebagai penyubur tanah karena mampu bersimbiosis dengan bakteri 
rhizobium, budidaya mudah dan hama yang menyerang relatif sedikit. Namun demikian, produksi kacang hijau di Indonesia masih rendah dan belum mampu memenuhi kebutuhan domestik. Kedepan peranan tanaman kacang hijau menjadi penting dan strategis bagi kehidupan dan perekonomian masyarakat.

Komoditas ini dibudidayakan oleh sejumlah besar petani yang tersebar di wilayah Indonesia dan hasilnya dibutuhkan oleh banyak pihak,tidak hanya sebagai bahan pangan melainkan juga bahan baku utama berbagai industri pangan dan non pangan skala rumah tangga sampai skala besar ( Balitkabi, 2006 ).

Produktivitas kacang hijau ditingkat petani relatif masih rendah yaitu rata-rata 1,0 ton/ha (Balitkabi, 2006). Rendahnya produktivitas kacang hijau di lahan pasang surut di Jambi disebabkan oleh ketersediaan benih bermutu terbatas, waktu tanam, kekeringan/tata air, pemupukan, hama penyakit, pasca panen dan harga. Peluang peningkatan produksi kacang hijau masih cukup besar dengan penerapan teknologi budidaya kacang hijau melalui pendekatan pengelolaan tanaman terpadu (PTT) dan hasil penelitian menunjukkan bahwa produktivitas kacang hijau berkisar 1,54 t/ha $-3,03$ t/ha (Balitkabi, 2006).

Salah satu alternatif untuk mempertahankan dan meningkatkan hasil tanaman kacang hijau adalah dengan pemberian pupuk organik cair. Pupuk organik cair tidak menimbulkan efek buruk bagi kesehatan tanaman karena bahan dasarnya alamiah, sehingga mudah diserap secara menyeluruh oleh tanaman. Pupuk organik cair kebanyakan diaplikasikan melalui daun atau disebut sebagai pupuk cair foliar yang mengandung hara makro dan mikro esensial (N, P, K, S, Ca, Mg, B, $\mathrm{Mo}, \mathrm{Cu}, \mathrm{Fe}, \mathrm{Mn}$, dan bahan organik).

Pupuk organik cair mempunyai beberapa manfaat diantaranya dapat mendorong dan meningkatkan pembentukan klorofil daun dan pembentukan bintil akar pada tanaman leguminosa sehingga meningkatkan kemampuan fotosintesis tanaman dan menyerap nitrogen dari udara (Yusuf, 2010).

Terdapat dua jenis pupuk yang digunakan untuk meningkatkan pertumbuhan dan produksi tanaman, yaitu: pupuk organik dan pupuk anorganik. Pupuk organik adalah pupuk yang berasal dari pupuk kandang atau kotoran hewan yang sudah mengalami dekomposisi oleh mikroorganisme tanah, sedangkan pupuk anorganik adalah pupuk yang dibuat dari pabrik yang unsur haranya sengaja ditambahkan ke dalam pupuk tersebut sebagai suatu unsur hara yang dikandung oleh pupuk itu. Umumnya pupuk organik yang dikenal oleh petani berupa pupuk kompos, pupuk hijau dan pupuk kandang, sedangkan pupuk anorganik merupakan pupuk yang dibuat di pabrik-pabrik dari bahan-bahan kimia yang berkadar tinggi yang dapat membantu pertumbuhan dan produksi tanaman. Pupuk anorganik mengandung beberapa keutamaan seperti kadar unsur hara yang tinggi, kemampuan menyerap dan melepaskan airnya tinggi serta mudah larut dalam air, sehingga mudah diserap tanaman. Umumnya dikenal petani adalah pupuk urea, SP-36, dan pupuk KCl. Sesuai dengan perkembangan potensi pasar dan kadar kandungan pupuk SP-36 yang setiap saat berubah- ubah, maka pupuk SP-36 yang merupakan unsur dari pupuk $\mathrm{P}$ (phospor), maka dikenal pupuk phonska sebagai pengganti pupuk $\mathrm{P}$ dikalangan petani (Hardjowigeno, 1987).

Berdasarkan hasil penelitian (Yudiawati, $d k k, 2015)$ menyatakan bahwa kombinasi pemberian pupuk dolomit 4 ton/ha + NPK $50 \mathrm{~kg} / \mathrm{ha}$ + Urine sapi 25 $\mathrm{ml} / \mathrm{l}$ air memberikan pengaruh nyata terhadap pertumbuhan dan hasil kedelai pada lahan masam Kabupaten Bungo.

Tujuan penelitian ini adalah untuk mengetahui respon Kacang Hijau Varietas Murai terhadap pemberian beberapa jenis pupuk pada tanah Ultisol dan untuk mengetahui kombinasi pemberian 
beberapa jenis pupuk yang terbaik terhadap tanaman kacang hijau varietas murai pada tanah Ultisol

\section{METODE PENELITIAN \\ Tempat dan Waktu penelitian}

Penelitian ini dilaksanakan dilahan percobaan Fakultas Pertanian Universitas Muara Bungo, dengan ketinggian 101 meter diatas permukaan laut, dengan temperatur udara berkisar antara $25^{\circ} \mathrm{C}-$ $31^{\circ} \mathrm{C}$, dengan rata - rata curah hujan per bulan adalah 179 - $279 \mathrm{~mm}$ pada bulan basah dan 68 - $106 \mathrm{~mm}$ pada bulan kering dengan tanah jenis Ultisol. Penelitian ini dilaksanakan pada tanggal 01 Desember sampai dengan 28 Februari 2017.

\section{Bahan dan Alat}

Adapun bahan yang digunakan dalam penelitian ini yaitu terdiri dari benih kacang hijau Varietas Murai, urine sapi, tetes tebu, EM4, decis, dan pupuk dolomit, pupuk KCL.

Alat yang digunakan terdiri dari cangkul, parang, hand sprayer, tali rafia, meteran, ember, selang bening, plastik, botol aqua, kertas label, timbangan digital, dan alat-alat tulis.

\section{Rancangan Penelitian}

Penelitian ini mengunakan

Rancangan Acak Kelompok (RAK) dengan 5 perlakuan dan 4 ulangan. Adapun perlakuan sebagai berikut :

(P0) : Pupuk Dolomit 0 t/ha,Pupuk $\mathrm{KCl} 0$ $\mathrm{kg} / \mathrm{ha}$ dan Fermentasi Urine Sapi 0 $\mathrm{ml} / \mathrm{l}$ air,

(P1) : Pupuk Dolomit 2 t/ha, Pupuk KCl $25 \mathrm{~kg} / \mathrm{ha}$ dan Fermentasi Urine Sapi $100 \mathrm{ml} / \mathrm{l}$ air,

(P2) : Pupuk Dolomit 4 t/ha, Pupuk KCl $50 \mathrm{~kg} / \mathrm{ha}$ dan Fermentasi Urine Sapi $200 \mathrm{ml} / \mathrm{l}$ air,

(P3) : Pupuk Dolomit 6 t/ha, Pupuk KCl $75 \mathrm{~kg} / \mathrm{ha}$ dan Fermentasi Urine Sapi $300 \mathrm{ml} / \mathrm{l}$ air,

(P4) : Pupuk Dolomit 8 t/ha, Pupuk KCl $100 \mathrm{~kg} / \mathrm{ha}$ dan Pupuk Urine Sapi 400 $\mathrm{ml} / \mathrm{l}$ air
Tiap petak percobaan ada 24 tanaman jadi tanaman keseluruhannya sebanyak 480 tanaman, tiap petak diambil 2 tanaman sampel, jadi jumlah tanaman sampel keseluruhan ada 40 tanaman sampel.

\section{Pelaksanaan Penelitian}

Pengolahan lahan diawali dengan pengukuran lahan yang sesuai dengan kebutuhan, kemudian lahan dibersihkan dari gulma, pengolahan tanah dilakukan 2 kali, pencangkulan pertama sedalam 30 $\mathrm{cm}$ fungsinya untuk memecahkan bongkahan tanah agar memperoleh tanah yang gembur. Lahan yang telah diola tersebut, kemudian dibuat petak - petak percobaan dengan ukuran $120 \mathrm{~cm}$ x 180 $\mathrm{cm}$. Denah unit petak dan tanaman percobaan dicantumkan pada lampiran 1 dan 2.

Penanaman dilakukan dengan menggunakan tugal dengan kedalaman lubang kira - kira $2 \mathrm{~cm}$ dan tiap lubang diisi 3 butir benih kacang hijau, dengan menggunakan jarak tanam $30 \times 30 \mathrm{~cm}$

Penyiangan dilakukan pada umur 14 dan 28 hst dengan cara dikored atau menggunakan cangkul. Pembumbunan dilakukan bersamaan dengan melakukan penyiangan dengan cara meninggikan tanah yang terletak pada bagian bawah (disekitar perakaran tanaman). Setelah benih kacang hijau ditanam, dilakukan penyiraman 2 kali sehari, yaitu pada pagi dan sore hari, kecuali keadaan tanah lembab atau hujan.

Pada umur tanaman 35 hst tanaman kacang hijau diserang hama semut dan dilakukan pengendalian hama dengan menerapkan konsep Pengendalian Hama Terpadu (PHT) dengan menyemprotkan insektisida decis dosis 10 cc/liter air sebanyak 2 kali pada tanaman yang terkena hama tersebut. Panen kacang hijau varietas murai dilakukan sebanyak dua kali yatu pada umur 60 dan 64 hari setelah tanam saat polong berwarna coklat atau hitam dan masih utuh, pemanenan di potong pada ujung tangkai buah menggunakan 
gunting

Pemberian dolomit di lakukan sesudah pengolahan tanah yang sudah di buat petakan, pemberian dolomit di taburkan pada setiap petak, dengan takaran masing-masing sesuai dengan perlakuan yaitu $\mathrm{P} 0: 0 \mathrm{~kg} /$ petak, $\mathrm{P} 1: 0,432$ $\mathrm{kg} /$ petak, P2 : 0,864 kg/petak, P3 : 1,296 $\mathrm{kg} /$ petak, dan P4 1,728 kg/petak

Perlakuan fermentasi urine sapi diberikan sebanyak 4 kali, dengan interval pemberian 10 hari sekali, pemberian urine sapi dengan menggunakan hand spayer, yang dilakukan pada sore hari. Perlakuan dilakukan dengan cara disemprot pada bagian daun tanaman sesuai dengan perlakuan.

Pupuk $\mathrm{KCl}$ di berikan pada saat tanaman berumur 14 hari setelah tanam dengan cara di kocorkan di dekat lingkaran tanaman kacang hijau. Pemberian pupuk $\mathrm{KCl}$ diberikan sesuai dengan masing-masing perlakuan yaitu : $\mathrm{KCl} 0 \mathrm{~kg} / \mathrm{ha}(0 \mathrm{~kg} /$ petak$), \mathrm{KCl} 25 \mathrm{~kg} / \mathrm{ha}$ $(5,4 \mathrm{~g} /$ petak $), \quad \mathrm{KCl} \quad 50 \mathrm{~kg} / \mathrm{ha} \quad(10,8$ $\mathrm{g} /$ petak), $\mathrm{KCl} 75 \mathrm{~kg} / \mathrm{ha}(16,2 \mathrm{~g} /$ petak) dan $\mathrm{KCl} 100 \mathrm{~kg} / \mathrm{ha}(21,6 \mathrm{~g} /$ petak).

\section{Variabel Pengamatan}

Variabel pengamatan meliputi performa keragaan dan hasil tanam : Tinggi tanaman,Jumlah Cabang Primer (buah), Lingkar Batang ( $\mathrm{cm})$, Jumlah Polong Isi Per tanaman (buah), Jumlah Biji Pertanaman (Biji )

Dan Hasil Biji Kering Per hektar (ton)

\section{Analisis Data}

Untuk mengetahui pengaruh perlakuan dari variabel yang diamati, maka dilakukan uji statistik dengan mengunakan sidik ragam (anova) apabila berpengaruh nyata maka dilanjutkan dengan uji Ducan Multiple Range Test (DNMRT) pada taraf 5\%.

\section{HASIL DAN PEMBAHASAN}

\section{Tinggi tanaman $(\mathrm{cm})$}

Berdasarkan hasil analisis ragam menunjukkan bahwa respon kacang hijau varietas murai terhadap pemberian beberapa jenis pupuk menunjukan pengaruh tidak nyata terhadap tinggi tanaman (Lampiran 6). Rataan tinggi tanaman $(\mathrm{cm})$ masing-masing perlakuan pengaruh kombinasi pemberian beberapa jenis pupuk dapat dilihat pada Tabel 1 .

Tabel 1. Rataan Tinggi Tanaman Kacang Hijau Terhadap Kombinasi Pemberian Beberapa Jenis Pupuk

\begin{tabular}{|c|c|}
\hline Perlakuan & $\begin{array}{c}\text { Rata-rata } \\
(\mathrm{cm})\end{array}$ \\
\hline P0 & 45,18 \\
P1 & 47,34 \\
P2 & 41,59 \\
P3 & 43,92 \\
P4 & 45,91 \\
\hline \multicolumn{2}{|c|}{ KK = 7,01 \% } \\
Keterangan : Perlakuan tidak \\
berpengaruh \\
terhadap tinggi tanaman \\
(cm) (P $>0,05)$
\end{tabular}

Tabel 1 menunjukkan bahwa kombinasi pemberian beberapa jenis pupuk yang diberikan tidak memberikan respon terhadap tinggi tanaman kacang hijau varietas murai. Hal ini diduga kombinasi pupuk yang diberikan belum sepenuhnya bereaksi yang disebabkan oleh pupuk dolomit belum bereaksi sepenuhnya dengan tanah sehingga diduga $\mathrm{pH}$ tanah masih bersifat asam yang menyebabkan tanaman belum optimal menyerap unsur hara untuk mendukung pertumbuhan seperti tinggi tanaman, sekalipun sudah memperoleh tambahan unsur hara dari pupuk $\mathrm{KCl}$ dan fermentasi urine sapi. Menurut Rosmarkam dan Yuwono (2002), pada $\mathrm{pH}$ asam kelarutan $\mathrm{Al}$ dan $\mathrm{Fe}$ tinggi, akibatnya pada $\mathrm{pH}$ sangat rendah pertumbuhan tanaman tidak normal karena suasana $(\mathrm{pH})$ tidak sesuai, kelarutan beberapa unsur menurun, ditambah lagi 
dengan adanya keracunan $\mathrm{Al}$ dan Fe. Gardner, dkk. (1991) menyatakan pH tanah merupakan faktor utama yang mempengaruhi daya larut dan mempengaruhi ketersediaan nutrisi tanaman, lebih lanjut dikatakan nutrisi lebih banyak tersedia dalam $\mathrm{pH}$ antara 6,0 dan 7,0 .

Pupuk $\mathrm{KCl}$ mengandung hara Kalium (K). Kekurangan unsur kalium berakibat pada gangguan fotosintesis yang mengakibatkan unsur hara yang terdapat pada fermentasi urine sapi yang disemprot pada bagian daun tanaman juga terganggu. Subandi (2013) menyatakan gangguan pada pembukaan dan penutupan stomata akibat tanaman kahat (deficiency) $\mathrm{K}$ akan menurunkan aktivitas fotosintetis karena terganggunya pemasukan $\mathrm{CO}_{2}$ ke daun. Lebih lanjut Setyamidjaja, (1986) menjelaskan bahwa mekanisme masuknya hara melalui daun berhubungan dengan proses membuka dan menutupnya stomata. Membukanya stomata merupakan proses yang diatur oleh tekanan turgor dari sel-sel penutup. Adapun tekanan turgor sebanding dengan kandungan karbondioksida dari ruang di bawah stomata. Meningkatnya tekanan turgor akan membuka lubang stomata bersama-sama dengan masuknya air.

Pengaruh perlakuan $\mathrm{K}$ terhadap tinggi tanaman berhubungan dengan meningkatnya $\mathrm{pH}$ tanah. Kekurangan atau kahat $\mathrm{K}$ akan menurunkan aktivitas fotosintesis yang diduga menyebabkan fermentasi urine sapi yang disemprotkan lewat daun belum dapat diserap oleh tanaman sehingga unsur hara seperti IAA (indol asetat acid) yang terkandung dalam fermetasi urine sapi belum sepenuhnya dimanfaatkan oleh tanaman yang berdampak pada pertumbuhan tinggi tanaman terhambat. Menurut Artanti (2007), IAA dikenal sebagai auksin utama pada tanaman yang berfungsi untuk pertumbuhan batang tanaman.

\section{Jumlah Cabang Primer (buah)}

Berdasarkan hasil analisis ragam menunjukkan bahwa respon kacang hijau varietas murai terhadap pemberian beberapa jenis pupuk menunjukan pengaruh nyata terhadap jumlah cabang primer (Lampiran 7). Rataan jumlah cabang primer (buah) yang dihitung setelah panen pada masing-masing perlakuan pengaruh kombinasi pemberian beberapa jenis pupuk Tabel 2 .

Tabel 2. Rataan Jumlah Cabang Primer Tanaman Kacang Hijau Terhadap Kombinasi Pemberian Beberapa Jenis Pupuk

\begin{tabular}{|c|c|}
\hline Perlakuan & Rata - rata (buah) \\
\hline P0 & $0,75 \mathrm{~b}$ \\
P1 & $2,88 \mathrm{a}$ \\
P2 & $2,19 \mathrm{a}$ \\
P3 & $1,72 \mathrm{a}$ \\
P4 & KK = 21,48 \% \\
\hline \multicolumn{3}{|c|}{ Angka-angka yang diikuti } \\
Keterangan : & oleh huruf kecil yang \\
& berbeda pada kolom yang \\
& sama menunjukkan berbeda \\
& nyata menurut uji DNMRT \\
& pada taraf 5\%.
\end{tabular}

Tabel 2 menunjukkan bahwa respon kacang hijau varietas murai pada perlakuan P0 berbeda secara nyata dengan semua perlakuan (P1, P2 P3 dan P4). Rataan jumlah cabang primer tanaman kacang hijau paling sedikit terdapat pada perlakuan P0 yaitu 0,75 buah sedangkan rataan jumlah cabang primer terbanyak terdapat pada perlakuan P2 yaitu 2,19 buah dan tidak beda dengan perlakuan P1, P2, P3 dan P4 sehingga perlakuan P1 merupakan perlakuan terbaik terhadap jumlah cabang primer tanaman kacang hijau.

Perbedaan respon yang ditunjukkan tanaman akibat pemberian beberapa jenis pupuk dibandingkan dengan tanpa pemberian beberapa jenis pupuk, diduga disebabkan oleh pupuk dolomit yang di aplikasikan sudah bereaksi dengan tanah sehingga unsur hara yang tekandung dalam pupuk yang diberikan baik lewat daun berupa fermentasi urine sapi maupun lewat 
tanah berupa pupuk $\mathrm{KCl}$ dapat dimanfaatkan dan diserap oleh oleh tanaman sehingga cabang primer tanaman kacang lebih banyak.

Dolomit mengandung unsur $\mathrm{Mg}$ dan Ca. Unsur $\mathrm{Ca}$ dapat membantu mengaktifkan enzim tanaman, membentuk senyawa-senyawa yang merupakan bagian dari dinding sel yang akan membantu memperkuat struktur tanaman, merangsang perkembangan akar dan daun, mempengaruhi hasil secara tidak langsung melalui penurunan kemasaman tanah. Sedangkan unsur $\mathrm{Mg}$ mempunyai fungsi yang khas, yaitu sebagai inti dari molekul klorofil sehingga berperan dalam proses fotosintesis, membantu peranan hara $\mathrm{S}$, demikian pula sebaliknya. Selain itu $\mathrm{Mg}$ juga berfungsi membantu translokasi fosfor dalam tanaman (Hakim et al. 1986; Winarso 2005)

Pupuk KCL merupakan pupuk an organik yang mengandung unsur hara Kalium (K). Nyakpa et al. (1998) menyatakan bahwa fungsi kalium secara fisiologis adalah metabolisme karbohidrat yaitu pembentukan, pemecahan dan translokasi pati dalam jaringan tanaman serta metabolisme nitrogen dan sintesis protein.

Dengan tersedia unsur $\mathrm{K}$ bagi tanaman sehingga pupuk organik berupa fermentasi urine sapi yang diberikan lewat daun dapat diserap dengan baik oleh tanaman yang berdampak pada pertumbuhan tanaman dalam hal ini jumlah cabang primer. Syarief (1989) menyatakan bahwa dengan tersedianya unsur hara dalam jumlah yang cukup pada saat pertumbuhan vegetatif, maka proses fotosintesis akan berjalan aktif, sehingga proses pembelahan, pemanjangan dan diffrensiasi sel akan berjalan dengan lancar. Kacang hijau dapat tumbuh dengan baik jika kebutuhkan hara N,P dan $\mathrm{K}$ yang merupakan unsur hara utama dapat tersedia. Lingga (2002) menyatakan bahwa tanaman didalam proses metabolisme ditentukan oleh ketersediaan hara tanaman terutama
Nitrogen, Fosfor dan Kalium dalam jumlah yang cukup pada fase pertumbuhan vegetatif dan pertumbuhan generatifnya.

Selain itu Solikun dan Masdiko (2005), menyatakan fermentasi urine sapi secara ilmiah mengandung zat pengatur tumbuh yaitu auksin golongan IAA. Sedangkan mekanisme kerja hormon tersebut dijelaskan oleh Abidin (1992), bahwa auksin menginisiasi pemanjangan sel dengan cara mempengaruhi pengendoran/pelenturan dinding sel. Auksin memacu protein tertentu yang ada di membran plasma sel tumbuhan untuk memompa ion $\mathrm{H}^{+}$ke dinding sel. Ion $\mathrm{H}^{+}$ ini mengaktifkan enzim tertentu sehingga memutuskan beberapa ikatan silang hidrogen rantai molekul selulosa penyusun dinding sel. Sel tumbuhan kemudian memanjang akibat air yang masuk secara osmosis. Setelah pemanjangan ini, sel terus tumbuh dengan mensintesis kembali material dinding sel dan sitoplasma.

\section{Lingkar Batang (cm)}

Berdasarkan hasil analisis ragam menunjukkan bahwa respon kacang hijau varietas murai terhadap pemberian beberapa jenis pupuk menunjukan pengaruh tidak nyata terhadap lingkar batang (Lampiran 9). Rataan lingkar batang $(\mathrm{cm})$ masing-masing perlakuan pengaruh kombinasi pemberian beberapa jenis pupuk dapat dilihat pada Tabel 3.

Tabel 3. Rataan Lingkar Batang Tanaman Kacang Hijau Terhadap Kombinasi Pemberian Beberapa Jenis Pupuk

\begin{tabular}{|c|c|}
\hline Perlakuan & Rata-rata $(\mathrm{cm})$ \\
\hline P0 & 1,34 \\
P1 & 1,38 \\
P2 & 1,71 \\
P3 & 1,58 \\
P4 & 1,76 \\
\hline \multicolumn{2}{|c|}{$\mathrm{KK}=22,76 \%$} \\
\hline
\end{tabular}

Keterangan : Perlakuan tidak berpengaruh nyata terhadap lingkar batang pokok $(\mathrm{P}>0,05)$ 
Tabel 3 menunjukkan bahwa respon kacang hijau varietas murai terhadap pemberian beberapa jenis pupuk yang diberikan tidak memberikan respon terhadap lingkar batang $(\mathrm{cm})$. Hal ini diduga kombinasi pupuk yang diberikan belum sepenuhnya bereaksi dengan tanah sehingga unsur hara yang dibutuhkan belum dapat dimanfaatkan oleh tanaman karena $\mathrm{pH}$ tanah masih bersifat asam meskipun tanah ataupun tanaman sudah memperoleh tambahan unsur hara dari pupuk $\mathrm{KCl}$ dan fermentasi urine sapi.

Belum sempurnanya reaksi dolomit pada tanah sehingga tanah masih bersifat masam. Pada tanah keadaan masam unsur hara belum mampu diserap oleh akar tanaman sehingga ketersediaan unsur hara seperti $\mathrm{Ca}$ dan $\mathrm{Mg}$ yang terkandung dalam dolomit itu sendiri belum dapat memacu turgor sel dan pembentukan klorofil sehingga proses fotosintesis menjadi menurun dan produk dari fotosintesis juga menurun. Kekurangan $\mathrm{Ca}$ akan mengakibatkan terhambatnya pertumbuhan sistem perakaran, sedangkan apabila kekurangan $\mathrm{Mg}$ kerja enzim dalam cyclus asam sitrat yang penting untuk respirasi terhambat dan kekurangan $\mathrm{P}$ dapat menyebabkan terhambatnya pertumbuhan akar dan pertumbuhan generative (Wijaya Adi, 1983; Sutarto dkk., 1987). Lebih lanjut Siregar dkk., (2000) dalam Mayura, $d k k$ (2015) menyatakan pada umumnya hara mudah diserap akar tanaman pada $\mathrm{pH}$ tanah netral karena pada $\mathrm{pH}$ tersebut kebanyakan hara mudah larut dalam air. Setiap tanaman memiliki $\mathrm{pH}$ optimum untuk pertumbuhannya, apabila $\mathrm{pH}$ nya tidak sesuai maka pertumbuhan tanaman akan terhambat.

\section{Jumlah Polong Isi Per tanaman (buah)}

Berdasarkan hasil analisis ragam menunjukkan bahwa respon kacang hijau varietas murai terhadap pemberian beberapa jenis pupuk menunjukan pengaruh nyata terhadap jumlah polong isi pertanaman (buah) (Lampiran 10). Rataan jumlah polong isi pertanaman (buah) pada masing-masing perlakuan pengaruh kombinasi pemberian beberapa jenis pupuk dapat dilihat pada Tabel 4 .

Tabel 4. Rataan Jumlah Polong Isi

Tanaman Kacang Hijau Terhadap

Kombinasi Pemberian Beberapa Jenis Pupuk

\begin{tabular}{|c|c|}
\hline Perlakuan & Rata - rata (buah) \\
\hline P0 & $7,75 \mathrm{~d}$ \\
P1 & $13,75 \mathrm{ab}$ \\
P2 & $10,88 \mathrm{c}$ \\
P3 & $15,39 \mathrm{a}$ \\
P4 & $12,25 \mathrm{bc}$ \\
\hline \multicolumn{2}{|c|}{ KK $=12,64 \%$} \\
\hline
\end{tabular}

Keterangan: Angka-angka yang diikuti oleh huruf kecil yang berbeda pada kolom yang sama menunjukkan berbeda nyata menurut uji DNMRT pada taraf $5 \%$.

Tabel 4 menjelaskan bahwa respon kacang hijau varietas murai pada perlakuan P0 berbeda dengan semua perlakuan (P1, P2, P3 dan P4) dan perlakuan P1 tidak berbeda dengan perlakuan P3. Hasil penelitian menunjukan bahwa rataan jumlah polong isi yang paling sedikit terdapat terdapat pada perlakuan P0 yaitu 7,75 buah sedangkan rataan jumlah polong isi pertanaman terbanyak terdapat pada perlakuan P3 yaitu 15,39 buah dan tidak berbeda dengan perlakuan P1 yaitu 13,75 buah sehingga perlakuan P1 merupakan perlakuan terbaik terhadap jumlah polong isi pertanaman kacang hijau.

Perlakuan P1 merupakan perlakuan terbaik terhadap jumlah polong isi pertanaman kacang hijau hal ini diduga unsur hara yang terkandung dalam kombinasi beberapa jenis pupuk yang diberikan (dolomit $2 \mathrm{t} / \mathrm{ha}+25 \mathrm{~kg} / \mathrm{ha} \mathrm{KCl}+$ $100 \mathrm{ml} / \mathrm{l}$ air Fermentasi Urine sapi) sudah dapat dimanfaatkan dan diserap oleh tanaman. Kuswandi (2003) menyatakan bahwa dengan pengapuran, $\mathrm{pH}$ tanah akan meningkat, suplai hara $\mathrm{Mg}$ dan $\mathrm{Ca}$ yang menggeser kedudukan $\mathrm{H}+$ dipermukaan koloid sehingga menetralisir kemasaman tanah. Soepardi (1983) juga menyatakan 
bahwa pengapuran menetralkan senyawasenyawa beracun dan menekan penyakit tanaman. Aminisasi, amonifikasi, dan oksidasi belerang nyata dipercepat oleh meningkatnya $\mathrm{pH}$ yang diakibatkan oleh pengapuran. Dengan meningkatnya $\mathrm{pH}$ tanah, maka akan menjadikan tersedianya unsur $\mathrm{N}, \mathrm{P}, \mathrm{K}$ dan $\mathrm{S}$, serta unsur mikro bagi tanaman. Dimana dengan tersedianya unsur hara tersebut kebutuhan hara dalam pembentukan maupun pengisian polong dapat tercapai khususnya unsur $\mathrm{P}$ dan $\mathrm{Ca}$. Hal ini diperkuat oleh Sutarto $d k k$. (1987), yang menyatakan bahwa tersedianya $\mathrm{Ca}$ dan unsur lainnya menyebabkan pertumbuhan generatif menjadi lebih baik, sehingga pengisian polong lebih sempurna dan mengakibatkan hasil menjadi lebih maksimal.

Dengan netralnya $\mathrm{pH}$ pada tanah ultisol sebagai media tanaman maka unsur hara $\mathrm{P}$ dapat tersedia bagi tanaman. Unsur $\mathrm{P}$ sangat diperlukan tanaman pada fase pertumbuhan generatif dalam pembentukan polong dan jika kekurangan unsure $\mathrm{P}$ menyebabkan biji tidak merata dan tidak bernas (Winarso, 2005).

Selain itu pemberian pupuk $\mathrm{KCl}$ juga manambah ketersedian unsur $\mathrm{K}$. Pemberian pupuk kalium secara fisiologis dapat meningkatkan jumlah polong dan jumlah biji pada tanaman kacang hijau dengan mekanisme metabolisme karbohidrat dari hasil fotosintesis. Seperti dikemukakan oleh Rosmarkan dan Yuwono (2002) Kalium lebih banyak berperan dalam pembentukan biji. Selain itu fungsi kalium adalah membentuk dan mengangkut karbohidrat, memperkuat tegaknya batang, biji tanaman menjadi lebih berisi dan padat, meningkatkan kualitas buah, menjadi tahan terhadap hama dan penyakit dan untuk perkembangan akar tanaman.

\section{Jumlah Biji Pertanaman (Biji)}

Berdasarkan hasil analisis ragam menunjukkan bahwa respon kacang hijau varietas murai terhadap pemberian beberapa jenis pupuk menunjukan pengaruh nyata terhadap jumlah biji pertanaman (biji) (Lampiran 12). Rataan jumlah biji pertanaman (buah) pada masing-masing perlakuan pengaruh kombinasi pemberian beberapa jenis pupuk dapat dilihat pada Tabel 5.

Tabel 5. Rataan Jumlah Biji Pertanaman Kacang Hijau Terhadap Kombinasi Pemberian Beberapa Jenis Pupuk

\begin{tabular}{|c|c|}
\hline Perlakuan & Rata - rata (biji) \\
\hline P0 & $40,53 \mathrm{c}$ \\
P1 & $70,15 \mathrm{a}$ \\
P2 & $46,20 \mathrm{c}$ \\
P3 & $73,63 \mathrm{a}$ \\
P4 & $57,85 \mathrm{~b}$ \\
\hline \multicolumn{2}{|c|}{ KK $=11,95 \%$} \\
\hline
\end{tabular}

Keterangan: Angka-angka yang diikuti oleh huruf kecil yang berbeda pada kolom yang sama menunjukkan berbeda nyata menurut uji DNMRT pada taraf $5 \%$.

Tabel 5 menujukan bahwa perlakuan P0 tidak berbeda dengan perlakuan P2 tapi berbeda dengan perlakuan P1, P3 dan P4 dan perlakuan P1 tidak berbeda dengan perlakuan P3. Hasil penelitian menunjukan bahwa rataan jumlah biji pertanaman yang paling sedikit terdapat pada perlakuan P0 yaitu 40,53 biji dan rataan jumlah biji pertanaman yang terbanyak terdapat pada perlakuan $\mathrm{P} 3$ yaitu 73,63 biji dan tidak berbeda dengan perlakuan P1 yaitu 70,15 biji. Sehingga perlakuan P1 merupakan perlakuan terbaik terhadap jumlah biji.

Dengan pemberian kombinasi beberapa jenis pupuk dengan perlakuan $\mathrm{P} 1$ (dolomit $2 \mathrm{t} / \mathrm{ha}+25 \mathrm{~kg} / \mathrm{ha} \mathrm{KCl}+100 \mathrm{ml} / \mathrm{l}$ air Fermentasi Urine sapi) jumlah biji pertanaman kacang hijau lebih banyak hal ini diduga penambahan pupuk $\mathrm{KCl}$ dan fermentasi urine sapi dapat dimanfaatkan sehingga unsur hara yang dibutuhkan oleh tanaman tersedia dalam keadaan cukup. Dalam proses pengisian polong, peran unsur-unsur hara sangat dibutuhkan untuk merangsang metabolisme dalam 
pembentukan biji kacang hijau khususnya unsur hara fosfor $(\mathrm{P})$ dan kalsium $(\mathrm{Ca})$.

Menurut Brady (1984), menyatakan bahwa pengapuran tanah masam akan menurunkan keberadaan aluminium, besi dan mangan. Sementara unsure fosfat yang terikat pada senyawa-senyawa aluminium hidroksi fosfat akan dipertukarkan dengan ion $\mathrm{OH}^{-}$sehingga fosfat menjadi lebih tersedia. Unsur hara phospor (P) merupakan unsur hara yang diperlukan tanaman. Unsur hara ini berfungsi merangsang pertumbuhan akar, membentuk titik tumbuh tanaman, mempercepat masa panen, merangsang pertumbuhan bunga, meningkatkan bunga menjadi buah (Hakim et al, 1986).

$$
\text { Menurut Sutedjo dan }
$$

Kartasapoetra (1987), unsur P merupakan salah satu unsur hara yang sangat membantu peningkatan produksi tanaman, peranan fosfor pada tanaman adalah dapat meningkatkan pertumbuhan akar semai, mempercepat serta memperkuat pertumbuhan tanaman muda menjadi dewasa, mempercepat pembungaan dan pemasakan buah dan biji. Rubatzky dan Yamaguchi (1998) juga menambahkan bahwa ketersediaan kalsium tanah sangat diperlukan agar biji dapat tumbuh dengan baik.

\section{Hasil Biji Kering Per hektar (ton)}

Hasil analisis ragam menunjukkan bahwa respon kacang hijau varietas murai terhadap pemberian beberapa jenis pupuk menunjukan pengaruh nyata terhadap hasil biji kering perhektar (ton) (Lampiran 12). Rataan hasil biji kering perhektar (ton) pada masing-masing perlakuan pengaruh kombinasi pemberian beberapa jenis pupuk dapat dilihat pada Tabel 6.

Tabel 6. Rataan Hasil Biji Kering Perhektar Kacang Hijau Terhadap Kombinasi Pemberian Beberapa Jenis Pupuk

\begin{tabular}{|c|c|}
\hline Perlakuan & Rata - rata (ton) \\
\hline P0 & $0,34 \mathrm{c}$ \\
P1 & $0,59 \mathrm{a}$ \\
P2 & $0,55 \mathrm{ab}$ \\
P3 & $0,62 \mathrm{a}$ \\
P4 & $0,50 \mathrm{~b}$ \\
\hline \multicolumn{2}{|c|}{ KK $=9,16 \%$} \\
\hline
\end{tabular}

Keterangan: Angka-angka yang diikuti oleh huruf kecil yang berbeda pada kolom yang sama menunjukkan berbeda nyata menurut uji DNMRT pada taraf $5 \%$.

Dari Tabel 6 dapat diketengahkan bahwa respon kacang hijau varietas murai pada perlakuan P0 berbeda secara nyata dengan semua perlakuan (P1, P2 P3 dan P4). Perlakuan P3 merupakan hasil biji kering perhektar kacang hijau tertinggi yaitu 0,62 ton hasilnya sama dengan perlakuan P1. Hal ini menunjukkan dengan perlakuan P1 telah mencukupi kebutuhan hara $\mathrm{N}, \mathrm{P}, \mathrm{K}, \mathrm{Ca}$ dan $\mathrm{Mg}$, kacang hijau varietas murai di tanah ultisol. Selain itu pada perlakuan P1 diduga dolomit dan penambahan pupuk $\mathrm{KCl}$ serta fermentasi urine sapi yang diberikan dapat memperbaiki sifat-sifat fisik dan kimia tanah sehingga pertumbuhan dan hasil bisa mencapai maksimal.

Meningkatnya hasil biji kering/ha kacang hijau disebabkan oleh kandungan kalsium $(\mathrm{Ca})$ yang terdapat dalam dolomite dapat merangsang pembentukan biji sehingga hasil biji kering tanaman kacang hijau meningkat. Hal ini didukung oleh Lingga dan Marsono (2013) yang menyatakan bahwa bagi tanaman kalsium bertugas merangsang pembentukan bulubulu akar, mengeraskan batang dan merangsang pembentukan biji.

Selain itu dengan pemberian dosis dolomit kedalam tanah maka unsur fosfor menjadi lebih tersedia bagi tanaman. Adapun fungsi fosfor terhadap tanaman antara lain sebagai bahan dasar pembentukan protein untuk meningkatkan energy ATP dan ADP dimana energy ini diperlukan dalam proses metabolism untuk 
pembentukan asam amino, tepung lemak dan senyawa organic lainnya sehinga mempercepat pembentukan bunga, buah dan pemasakan biji serta meningkatkan produksi biji-bijian (Lingga dan Marsono. 2013).

Selain itu unsur hara $\mathrm{K}$ yang diberikan memalui pupuk $\mathrm{KCl}$ dapat dimanfaatkan oleh tanaman, penambahan pupuk $\mathrm{KCl}$ akan menambah kandungan $\mathrm{K}^{+}$ yang berfungsi dalam dalam pembentukan pati untuk pengisian biji sehingga biji tanaman menjadi lebih berisi dan padat.

\section{KESIMPULAN DAN SARAN}

\section{Kesimpulan}

Berdasarkan hasil penelitian diatas dapat diambil kesimpulan sebagai berikut :

1. Respon kacang hijau varietas murai terhadap variabel tinggi tanaman $(\mathrm{cm})$ dan lingkar batang $(\mathrm{cm})$ menunjukan respon yang sama sementara pada jumlah cabang primer (buah), jumlah polong isi per tanaman (buah), jumlah biji pertanaman (biji) dan hasil biji kering per hektar (ton) memberikan respon yang berbeda.

2. Respon kacang hijau varietas murai pada perlakuan P1 (dolomit 2 t/ha + $\mathrm{KCl} 25 \mathrm{~kg} / \mathrm{ha}+100 \mathrm{ml} / \mathrm{l}$ air Fermentasi Urine sapi) merupakan perlakuan terbaik di tanah Ultisol.

\section{Saran}

Untuk mendapatkan hasil kacang hijau varietas murai yang maksimal di tanah ultisol pada kombinasi pemberian beberapa jenis pupuk (dolomit $+\mathrm{KCl}+$ Fermentasi urine sapi) maka disarankan untuk menggunakan kombinasi dengan dosis dolomit 2 t/ha + KCL $25 \mathrm{~kg} / \mathrm{ha}+100$ $\mathrm{ml} / \mathrm{l}$ air Fermentasi Urine sapi.

\section{DAFTAR PUSTAKA}

Abidin, 1992. Dasar Pengetahuan Ilmu Tanaman. Angkasa, Bandung.
Artanti, F.Y. Pengaruh Macam Pupuk Orgaik Cai dan Konsentrasi Terhadap Pertumbuhan Setek Tanaman Lada Stevia (Stevia rbaudiana Bertoni. M). Skripsi FP UNS. Surakarta.

Balitkabi. 2005. Teknologi budidaya kacang hijau (vigna radiata 1 .) Di lahan sawah Vol VI (I):89-95 Balai Pengkajian Teknologi Pertanian (BPTP) Sumatera B

Balitkabi. 2006. Produktıv...u Beberapa Varietas Kacang Hijau Melalui Pengelolaan Tanaman Terpadu (Ptt) Di Lahan Rawa Pasang Surut Balai Pengkajian Teknologi pertanian jambi (2009)

Buckman, H. O. dan N. C. Brady. Ilmu tanah. Gajah Mada University Press, Yogyakarta

Evita. 2009. Pengaruh berbagai konsentrasi pupuk organik cair terhadap pertumbuhan dan hasil tanaman kacang buncis (Phaseolus vulgaris L). Jurnal Agronomi, 13 (1) : $21-24$

Gardner, F. P., R. B. Pearce, R, L. Mitchell. 1991. Fisiologi Tanaman Budidaya. UI Press. Jakarta.

Hakim, N., Yusuf. N., A.M. Lubis., Nugroho. S.G., Diha. M.A., Hong. G.B dan H.H. Bailey. 1986. DasarDasar Ilmu Tanah. Universitas Lampung.

Hardjowiguno, 1987. Pertumbuhan Dan Produksi Kacang Hijau (Vigna radiata L.) Melalui Pemberian Pupuk Phonska, Gorontalo Utara.

Hasibuan, B. E. 2008. Pengolahan Tanah dan Air Lahan marjinal. USU. Medan. 
Hidayat dan Mulyani . 2005. Karakteristik

Sifat Kimia Sub Grup Tanah Ultisol di Beberapa Wilayah Sumatera Utara Vol IV (I) :1796 1803

Hidayat, 1995, kualitas benih kacang hijau (vigna radiata (1.) R. Wilczek) pada pertanaman monokultur dan tumpang sari dengan jagung (zea mays 1.) (2011-2012) Fakultas Pertanian, Universitas Gadjah Mada,

Kuswandi. 2003. Pengapuran Tanah Pertanian. Kanisius. Yogyakarta

Lingga, P. 2002. Pupuk dan Pemupukan. Penebar Swadaya. Jakarta

Lingga, P dan Marsono. 2013. Petunjuk Penggunaan Pupuk. Penebar Swadaya. Jakarta.

Marzuki dan Soeprapto. 2004. Botani Tanaman. Universitas Sumatra Utara. Medan.

Mayura. E, Yudarfis dan H. Idris. 2015. Pengaruh Pemberian Urine Sapi Pada Pertumbuhan Benih Tanaman Kayumanis Ceylon (Cinnamomum zeylanicum Blume.). Prosiding Seminar Perbenihan Tanaman Rempah dan Obat. Balai Penelitian Tanaman Rempah dan Obat Badan Penelitian dan Pengembangan Pertanian. Sumatera Barat. Solok

Nyakpa, M.Y., Lubis, A.M., Pulung, M.A., Amrah, A.G., Munawar, A.,Hong, G.B., \& Hakim, N. 1988. Kesuburan Tanah. Universitas Lampung. Lampung.

Purwono dan H. Purnamawati. 2009. Budidaya 8 Jenis Tanaman Pangan Unggul. Penebar Swadaya, Jakarta.
Purwono dan R. Hartono. 2008. Kacang Hijau. Penebar Swadaya, Jakarta.

Rosmarkam, A. dan N. W. Yuwono. 2002. Ilmu Kesuburan Tanah. Kanisius. Yogyakarta.

Rubatzky, V.E dan M. Yamaguchi, 1998. Sayuran Dunia, Prinsip, Produksi, dan Gizi. Edisi kedua. Penerjemah Catur Herison. ITB Press, Bandung. 